\title{
Angiotensin II Induces TSLP via an AT1 Receptor/NF-KappaB Pathway, Promoting Th17 Differentiation
}

\author{
Hui Zhao ${ }^{a, c}$ Ming Li $i^{a}$ Lei Wang ${ }^{b}$ Yousu Su ${ }^{b}$ Hongcheng Fang ${ }^{b}$ Jing Lin ${ }^{a}$ \\ Nilesh Mohabeera Dazhu Lia \\ aDepartment of Cardiology, Institute of Cardiovascular Diseases, Union Hospital, Tongji Medical \\ College, Huazhong University of Science and Technology, Wuhan; 'bepartment of Cardiology, \\ Shenzhen Sixth People's Hospital (Nanshan Hospital), Huazhong University of Science and Technology \\ Union Shenzhen Hospital, Shenzhen; 'Institute of Cardiovascular Diseases, Three Gorges University, \\ Department of Cardiology, Yichang Central People's Hospital, Yichang
}

\section{Key Words}

Atherosclerosis - Hypertension - T helper 17 cells • Angiotensin II - Thymic stromal lymphopoietin

\begin{abstract}
Background: Adaptive immunity plays a critical role in atherosclerosis and hypertension. T helper 17 (Th17) cells, as a new T-cell lineage, are involved in cardiovascular diseases. Dendritic cells (DCs) are the professional antigen-presenting cells with the pivotal role in orchestrating adaptive immunity. Thymic stromal lymphopoietin (TSLP) can activate DCs and trigger adaptive immune responses. What the role of TSLP in atherosclerosis and hypertension has not been investigated. Methods and Results: We measured the expression of TSLP in primary rat vascular smooth muscle cells (VSMCs) exposed to angiotensin II (Ang II) and evaluated the capacity of TSLP induced by Ang II to induce the differentiation of Th17 Cells. We then sought to identify the involved upstream regulatory mechanisms. We found that VSMCs express TSLP in response to Ang II in an AT1 receptor/NF-KappaB manner. TSLP can induce the differentiation of Th17 Cells by triggering DCs. Conclusion: Through DC activation, Ang II-induced TSLP enhances Th17-driven immune response in atherosclerosis and hypertension.
\end{abstract}

Copyright @ 2012 S. Karger AG, Basel

\section{Introduction}

Cardiovascular disease (CVD) is the leading cause of morbidity and mortality in many countries [1]. Atherosclerosis and hypertension are the most common forms of CVD, and 
they have generally severe consequences both for the individual person and society [2, 3]. A growing body of evidence suggests that the adaptive immune response plays an important role in atherosclerosis and hypertension [4-7]. Th17 cells, characterized by production of the inflammatory cytokine IL-17 [8], have been recently linked to the pathogenesis of several autoimmune and chronic inflammatory diseases, including atherosclerosis and hypertension [8-12]. Circulating Th17 cells and Th17-associated cytokines are positively related to the severity and progression of artery plaques in human and animal models $[8,12,13]$. The upregulation of Th17 immune response has also been found in the local atherosclerotic lesions. Based on evidence from current studies, as paralleled to atherosclerosis, the role of Th17 cells in hypertension is now starting to become clear. Th17 cells and increased T cell production of IL-17 are critical for the maintenance of angiotensin II (Ang II)-induced hypertension and vascular dysfunction $[11,14]$. Of note, antigen presentation is a key event in adaptive immune response. Dendritic cells (DCs), as the most potent professional antigenpresenting cells (APCs) $[15,16]$, can sense danger signals, polarize Th effector cells and orchestrate adaptive immunity. Our studies as well as work from others have demonstrated that DCs are closely associated with the pathological processes of cardiovascular system (esp. with Atherosclerosis) [17-22]. As such, it has not been hard to imagine that DCs could also play an indispensible role in hypertension [23]. Moreover, an excellent review by Sata et al. analyzed the renin-angiotensin system (RAS) in atherosclerosis [24]. Ang II, as the main effector molecule of the RAS, contributes to the development of atherosclerosis through inducing endothelial dysfunction, cellular proliferation, inflammation and production of reactive oxygen species (ROS) [24,25]. The relationship between Ang II and the pathogenesis of hypertension is well known. For many years it was believed that Ang II could merely regulate vascular tone and sodium balance, affecting blood pressure [26, 27]. Today, the picture is much more complex, with Ang II also activating immune cells and promoting cell infiltration into target organs to further aggravate hypertension [28]. In addition, clinical and experimental evidence indicate that Ang II via AT1 receptor activation is a central pathway to almost all the biological functions of Ang II [29, 30]. Angiotensin receptor blocker (ARB), antagonising the binding of Ang II to the AT1 receptor, is a cornerstone of our therapeutic strategies to reduce cardiovascular events by attenuating blood pressure elevation, as well as having anti-inflammatory, anti-proliferative, and oxidative stress lowering properties [29, 31-33]. However, the precise mechanisms underlying Ang II's role in the adaptive immune response and its relation to both atherosclerosis and hypertension are still largely unclear.

Thymic stromal lymphopoietin (TSLP) is a novel IL-7-like cytokine, primarily expressed by epithelial cells, where under inflammatory conditions, some other cells such as smooth muscle cells and fibroblasts, are also able to produce TSLP [34-36]. In confirmation of the expression data, TSLP can strongly activate DCs with several phenotypic changes, including improved survival, upregulation of major histocompatibility complex (MHC) class II and costimulatory molecules, and the production of a variety of chemokines [35, 36]. TSLP is, thus, involved in the modulation of both an innate and an adaptive immune response [35-38]. In some emerging papers, the relationship between TSLP and Th17 cells has been described. Human TSLP and TLR3 ligands promote differentiation of Th17 cells through DC activation [39]. But TSLP acts on T cells by reducing their capacity to produce IL-17 in another study [40]. Recently, IL-1 $\beta$ and TNF- $\alpha$ have been found to induce TSLP mRNA and protein release from human airway smooth muscle cells (HASMCs) [41, 42]. Furthermore, vascular smooth muscle cells (VSMCs), as a fundamental component of vascular wall, play an essential role in atherosclerosis and hypertension [43, 44]. In VSMCs, Ang II activates NF- $\kappa$ B, a major transcription factor in inflammatory responses, which induces the production of cell adhesion molecules (eg, vascular cell adhesion molecule-1 (VCAM-1), intercellular adhesion molecule-1 (ICAM-1)) and E-selectin, as well as chemokines (eg, monocyte chemoattractant protein (MCP-1), interleukin (IL)-6, and IL-8) [30, 45-47]. Renin-angiotensin system blockade is renoprotective in TSLP transgenic (TSLPtg) mice [48]. Until recently, whether Ang II stimulates TSLP expression in VSMCs has not been investigated. Therefore, in this study, we first measured the expression of TSLP in primary rat VSMCs exposed to Ang II and 
evaluated the capacity of TSLP induced by Ang II to induce the differentiation of Th17 Cells. We then sought to identify the involved upstream regulatory mechanisms, and attempted to provide a novel link between Ang II and DCs through TSLP, which may open new perspectives on the role of Th17 immune response in atherosclerosis and hypertension.

\section{Materials and Methods}

Isolation and Culture of VSMCs

Male Sprague-Dawley rats (weight 150-180 g) were obtained from the Laboratory Animal Institute of Tongji Medical College, Huazhong University of Science and Technology. Primary VSMCs were isolated from the thoracic aorta of Sprague-Dawley rats and cultured based on the published procedures [49]. Briefly, the rats were euthanized by decapitation. The thoracic aortas were dissected and carefully stripped clean of connective tissue and fat, rinsed extensively with Dulbecco's minimum essential medium (DMEM, Gibco, USA), containing 20\% newborn calf serum (NCS, Gibco, USA). After mechanical removal of adventitia, the arteries were cut longitudinally. The endothelium was softly scraped off with a miniature forceps. The media of the thoracic aorta was divided into tissue explants of $1 \mathrm{~mm}^{2}$. These adhered to the bottom of the culture flask, and the explants were incubated with DMEM containing 20\% NCS (pH 7.2) in humidified 5\% $\mathrm{CO}_{2} / 95 \%$ air atmosphere. VSMCs migrated from the explants within 1-2 weeks. They were capable of being passaged about 1 week after the first appearance of cells. VSMCs were identified by their characteristic hilland-valley growth pattern and immunocytological staining for $\alpha$-actin. All VSMCs were used for experiments between the 4 th and 10th passages. When the cells were grown to confluence, the medium was changed to serum-free DMEM for an additional $24 \mathrm{~h}$ culture prior to treatment. The investigation conforms to the Guide for the Care and Use of Laboratory Animals published by the U.S. National Institutes of Health (NIH Publication No. 85-23, revised 1996), and is granted by the Ethics Committee of Tongji Medical College, Huazhong University of Science and Technology.

\section{Cell Stimulations}

Confluent VSMCs (passages 4-10) were growth arrested by NCS deprivation for $24 \mathrm{~h}$ in DMEM medium. Cells were then stimulated in fresh NCS-free medium containing graded concentration $(0.01,0.1$, $1 \mu \mathrm{mol} / \mathrm{L}$ ) of Ang II (Sigma, USA) (without detectable levels of LPS), TNF- $\alpha$ (10 ng/mL) (R\&D Systems, USA) or medium alone. In some experiments, cells were pretreated for $30 \mathrm{~min}$ with the NF- $\kappa \mathrm{B}$ specific inhibitors PDTC $(10 \mu \mathrm{mol} / \mathrm{L})$ (Sigma, USA) or the selective AT1 receptor antagonist valsartan $(10 \mu \mathrm{mol} / \mathrm{L})$ (Novartis AG, Basel, Switzerland) before stimulation with Ang II $(0.1 \mu \mathrm{mol} / \mathrm{L})$ for different durations. Supernatants were collected at every time point, stored at $-70^{\circ} \mathrm{C}$ until analysis by ELISA.

\section{Immunohistochemistry (IHC)}

The cellular localization of TSLP expressed in VSMCs was assessed by specific immunohistochemical staining analysis utilizing a purified rabbit anti-murine TSLP Ab (ProSci Inc., USA). According to the manufacturer's instructions, the whole immunostaining procedure was performed using a commercial kit (EnVision ${ }^{\mathrm{TM}}$ Detection Kit, Gene Tech (Shanghai) Ltd., China) that employed the two-step procedure,

Cells were trypsinised from flasks and seeded onto sterile coverslips placed in six-well plates, so that there were $1 \times 10^{4}$ cells on each coverslip. Coverslips were incubated at $37^{\circ} \mathrm{C}$ in $5 \% \mathrm{CO}_{2}$. When grown to semiconfluence, cells were appropriately treated and incubated with different agent(s) according to the protocol as described above. Then the media were aspirated and cultured cells washed 3 times with 0.01 mol/L phosphate-buffered saline (PBS) ( $\mathrm{pH}$ 7.2-7.4), fixed for $1 \mathrm{~h}$ with $4 \%$ paraformaldehyde. Following fixation, cell-coated coverslips were rinsed three times for $5 \mathrm{~min}$ in PBS. The cultures were permeablised with $0.1 \%$ Triton X-100 for $15 \mathrm{~min}$ and subsequently washed. Endogenous peroxidase was blocked by $3 \% \mathrm{H}_{2} \mathrm{O}_{2}$ in absolute methanol for $10 \mathrm{~min}$ and coverslips then were washed again. Cells were incubated overnight at $4{ }^{\circ} \mathrm{C}$ followed by anti-TSLP rabbit polyclonal antibody $(2.5 \mu \mathrm{g} / \mathrm{mL})$, then exposed to a peroxidase-conjugated polymer anti-rabbit IgG (ChemMate ${ }^{\mathrm{TM}}$ DAKO EnVision ${ }^{\mathrm{TM}} / \mathrm{HRP}$, Rabbit/Mouse (ENV)) for $45 \mathrm{~min}$ at room temperature and washed again. The peroxidase labels were visualized, as the brown/ black reaction product, by incubating the cells with the fresh 3,3'-diaminobenzidine (DAB) fluid. Finally, Coverslips were rinsed in deionized water, counterstained with haematoxylin, differentiated with $0.1 \%$ 
hydrochloric acid, dried and mounted with neutral gums. The negative control group was carried out with the same steps as described above, but primary antibody was replaced by PBS. Every coverslip was counted in 5 randomly selected high power fields under light microscopy by one author. Images were collected using a telecytological microscope system (Olympus Ltd., Japan) with Digital Camera DXM1200 (Nikon, Japan) and analyzed with Software Image-Pro Plus Version 6.0 (MediaCybernetics, Bethesda, MD, USA).

\section{Enzyme-linked Immunosorbent Assay}

According to the manufacturer's protocol (R\&D Systems, USA), enzyme-linked immunosorbent assay (ELISA) for TSLP was performed to determine the levels of TSLP protein in the supernatants of the conditioned media from VSMC cultures after treatment as described in the previous section. The results were compared with a standard curve. Color development was measured at $450 \mathrm{~nm}$ by means of a spectrophotometer. Each sample was tested for these cytokines in triplicates. In all ELISA experiments including the following section both inter and intra assay variations were $<10 \%$, and the specificity was $>90.3 \%$.

\section{Real-time Reverse Transcription-polymerase Chain Reaction}

The level of TSLP mRNA expression was analyzed by real-time reverse transcription-polymerase chain reaction (Real-time RT-PCR). Cells were harvested from different groups, and total cellular RNA was isolated using Trizol reagent (Invitrogen, USA) according to the manufacturer's recommendations. RNA concentration and its purity were measured by a spectrophotometer. One microgram of total RNA was reversely transcripted into cDNA using RNA PCR Kit (Takara Biotechnology, Japan) and the cDNA was used as a template. The real-time PCR was carried out with Applied Biosystems Step One Real-Time PCR System (Applied Biosystem, USA) according to the manufacturer's protocol. A housekeeping genes GAPDH was used as an internal control for the PCRs. The sequences of the primer were as follows: TSLP (5'-CGA GCA AAT CGA GGA CTG TGA G-3' and 5'-GCA GTC GTC ATT GAG CGC TTC-3'); GAPDH (5'-AAC CTG CCA AGT ATG ATG ACA TCA-3' and 5'-TGT TGA AGT CAC AGG AGA CAA CCT-3'). The PCR reaction mixture was prepared with the SYBR Green I (Takara Biotechnology, Japan), cDNA, and the primers following the manufacturer's protocol. The amount of gene expression was then calculated as the difference $(\Delta \mathrm{Ct})$ between the $\mathrm{Ct}$ value of target gene and the Ct value of GAPDH. Fold changes in target gene mRNA were determined by the formula $2^{-\Delta \Delta C \mathrm{t}}$.

Isolation and culture of DCs and CD4+ $T$ cell

Myeloid dendritic cells (mDCs) were generated as previously described. Bone marrow cells were aspirated from the femurs and tibiae of Sprague-Dawley rats, and cultured in RPMI 1640 supplemented with $20 \% \mathrm{NCS}, 4 \mathrm{ng} / \mathrm{mL} \mathrm{rGM}-\mathrm{CSF}, 4 \mathrm{ng} / \mathrm{mL}$ IL-4, $2 \mathrm{mM}$ glutamine, $100 \mathrm{U} / \mathrm{mL}$ penicillin, $100 \mu \mathrm{g} / \mathrm{mL}$ streptomycin. Every 2 days, fresh media supplemented with rGM-CSF and IL-4 was added. Finally, non-adherent cells (which represented $\mathrm{mDCs}$ ) were collected. DC purity was evaluated by the technique of flow cytometry with cell surface markers for 0X62.

$\mathrm{T}$ cells were isolated from splenocyte suspension of Sprague-Dawley rats by ficoll density gradient centrifugation. $\mathrm{CD}^{+} \mathrm{T}$ cells ( $>92 \%$ purity) were obtained from leukocyte enriched fraction by positive selection using anti-CD4 ${ }^{+}$microbeads in a MiniMACs system (Miltenyi Biotech, Bergisch Gladbach, Germany).

\section{Flow cytometric analysis}

The mDCs were directly mixed with VSMCs from different groups by the transwell technique [50]. The expressions of the costimulatory molecules on DCs were analyzed by Flow cytometry. Briefly, DCs from different groups were incubated with mouse anti-rat monoclonal OX62 (Serotec, UK), CD80 and CD86, MHC II antibodies (BD Pharmingen, USA) at $4^{\circ} \mathrm{C}$ for $30 \mathrm{~min}$, respectively. Cells were then washed twice with PBS which contains $2 \%$ bovine serum albumin and $0.1 \%$ NaN3. Matched isotypes were used as the negative control to correct for nonspecific antibody binding. Incubated cells were re-suspended in $500 \mu \mathrm{L}$ PBS with $1 \%$ paraformaldehyde and immediately were run on a FACS LSR $\alpha$ (Becton Dickinson, USA). The percentage of positive cells was determined by the Cell Quest program (Becton Dickinson, USA).

In some groups, anti-murine TSLP-neutralizing antibody $(20 \mu \mathrm{g} / \mathrm{mL})$ was added in the co-culture. After $48 \mathrm{~h}$ of co-culture, DCs were collected and washed three times with PBS to remove excess cytokines. The remaining cells and CD $4^{+} \mathrm{T}$ cells were co-cultured at a DC:T-cell ratio of 1:5 for $48 \mathrm{~h}$. The amount of Th17associated cytokines in the culture supernatants was measured using the specific ELISA kit. Intracellular staining for IL-17 in CD4+ T cell was measured. Thereinto, rabbit anti-rat IL-17 antibody was got from Santa 
Cruz Biotechnology. Cell staining was determined by the technique of flow cytometry and analyzed with the Cell Quest software (Becton Dickinson, USA).

\section{Nuclear Extracts and EMSA to NF- $\kappa$ B Consensus Oligonucleotide}

Furthermore, to better understand the intracellular mechanisms by which Ang II induces TSLP expression in VSMCs, we carried out more experiments designed to test the hypothesis that NF- $\mathrm{kB}$ might be involved in mediating this phenomenon. Nuclear protein extracts were prepared [51]. In brief, as described in Figure legend 1, confluent VSMCs were incubated with different agent(s) then washed with PBS, and harvested by scraping. After being pelleted by centrifugation ( 10 minutes $3000 \mathrm{~g})$, cells were resuspended in ice-cold hypotonic lysis buffer (in mmol/L: HEPES 10 [pH7.9], $\mathrm{KCl} 10, \mathrm{MgCl}_{2} \cdot 6 \mathrm{H}_{2} \mathrm{O}$ 1.5, EDTA 0.1, DTT 1, and PMSF 1) and homogenized. Cell suspensions were incubated for $5 \mathrm{~min}$ on ice, then briefly vortexed following the addition of $0.1 \%$ Nonidet P- 40 . Samples were centrifuged $\left(5\right.$ minutes $12.000 \mathrm{~g}, 4^{\circ} \mathrm{C}$ ) and supernatants removed. Nuclei were resuspended in an ice-cold hypertonic salt buffer (in mmol/L: HEPES 20 [pH 7.9], $\mathrm{NaCl} 420$, EDTA 0.1, $\mathrm{MgCl}_{2} \cdot 6 \mathrm{H}_{2} \mathrm{O}$ 1.5, DTT 1, and PMSF 1) and incubated on ice for $30 \mathrm{~min}$ with intermittent vortexing. Samples were centrifuged $\left(15\right.$ minutes $\left.12.000 \mathrm{~g}, 4^{\circ} \mathrm{C}\right)$, and the supernatant containing nuclear proteins was stored at $-70^{\circ} \mathrm{C}$ until further use. Protein concentration in supernatants was determined using a BCA ${ }^{\mathrm{TM}}$ Protein Assay Kit (Pierce Inc., USA).

The levels of NF- $\mathrm{KB}$ proteins in nuclear extracts from the cells were analyzed by electrophoretic mobility shift assay (EMSA). We use a commercial kit (Light Shift ${ }^{\mathrm{TM}}$ Chemiluminescent EMSA kit, Pierce, USA) with the biotin-labeled oligonucleotide probe containing the sequence of the NF- $\mathrm{KB}$ binding site: forward 5'-AGT TGA GGG GAC TTT CCC AGG C-3'; reverse 5'-GCC TGG GAA AGT CCC CTC AAC T-3'. According to the manufacturer's instructions, the binding reactions were performed for 20 minutes in $10 \mathrm{mmol} / \mathrm{L}$ Tris- $\mathrm{HCl}$ (pH 7.5), $50 \mathrm{mmol} / \mathrm{L} \mathrm{KCl}, 5 \mathrm{mmol} / \mathrm{L} \mathrm{MgCl}, 1 \mathrm{mmol} / \mathrm{L}$ dithiothreitol, $50 \mathrm{ng} / \mu \mathrm{L}$ poly (dI-dC), $0.05 \% \mathrm{NP}-40$, $2.5 \%$ glycerol, biotin 3 '-end-labeled double-stranded oligonucleotide, and nuclear protein extract (30 $\mathrm{\mu g} /$ well). Protein-DNA complex was separated from free DNA probe by electrophoresis in a non-denaturing $6 \%$ polyacrylamide gel in $0.5 \times$ TBE buffer and then transferred to a nylon membrane. The biotin end-labeled DNA was then detected by chemiluminescence. Images were collected using BioDoc-It 220 Imaging System (UVP Inc., USA) and analyzed for signals with Software Image-Pro Plus Version 6.0 (MediaCybernetics, Bethesda, MD, USA). Competition studies were performed by the addition of 100 -fold excess unlabeled oligonucleotide to the binding reaction.

\section{Statistical Analyses}

Results are shown as mean \pm SD of at least three independent experiments. The significance of differences was determined using ANOVA followed by Student-Newmann-Keuls multiple comparison tests. $P$ values of $<0.05$ were considered statistically significant. All statistical analyses were performed with SPSS 17.0 (SPSS Inc., Chicago, IL).

\section{Results}

Ang II Induced TSLP Expression in the Cytoplasm of VSMCs

In VSMCs, Ang II induces the production of cell adhesion molecules, chemokines and cytokines, which contribute to the initiation and progression of atherosclerosis and hypertension. To better understand the pathogenesis of atherosclerosis and hypertension, we first investigated whether the protein TSLP is expressed in primary rat VSMCs exposed to Ang II. Immunohistochemical staining was performed as described in Methods. Typical presentations were shown in Figure 1. A quantitative analysis of the TSLP staining was shown in bar graphs of Fig. 1. As a normal control, very weak or no staining was detectable in the smooth muscle cells incubated with NCS-free medium (MOD $=0.49 \pm 0.14$ ), while strongly positive staining for TSLP was evident in VSMCs incubated with Ang II ( $0.1 \mu \mathrm{mol} / \mathrm{L})$ or TNF- $\alpha$ $(10 \mathrm{ng} / \mathrm{mL})$ for $12 \mathrm{~h}(\mathrm{MOD}=280.40 \pm 18.88,219 \pm 34.11$, respectively, all $\mathrm{P}<0.001)$. TNF- $\alpha-$ treated group was shown here as the positive control. NF- $\kappa \mathrm{B}$ activation performs the broad function in inflammation and immunity, which is close related to various cardiovascular diseases. Additionally, the NF- $\mathrm{BB}$ signaling pathway has been reported to be involved in 


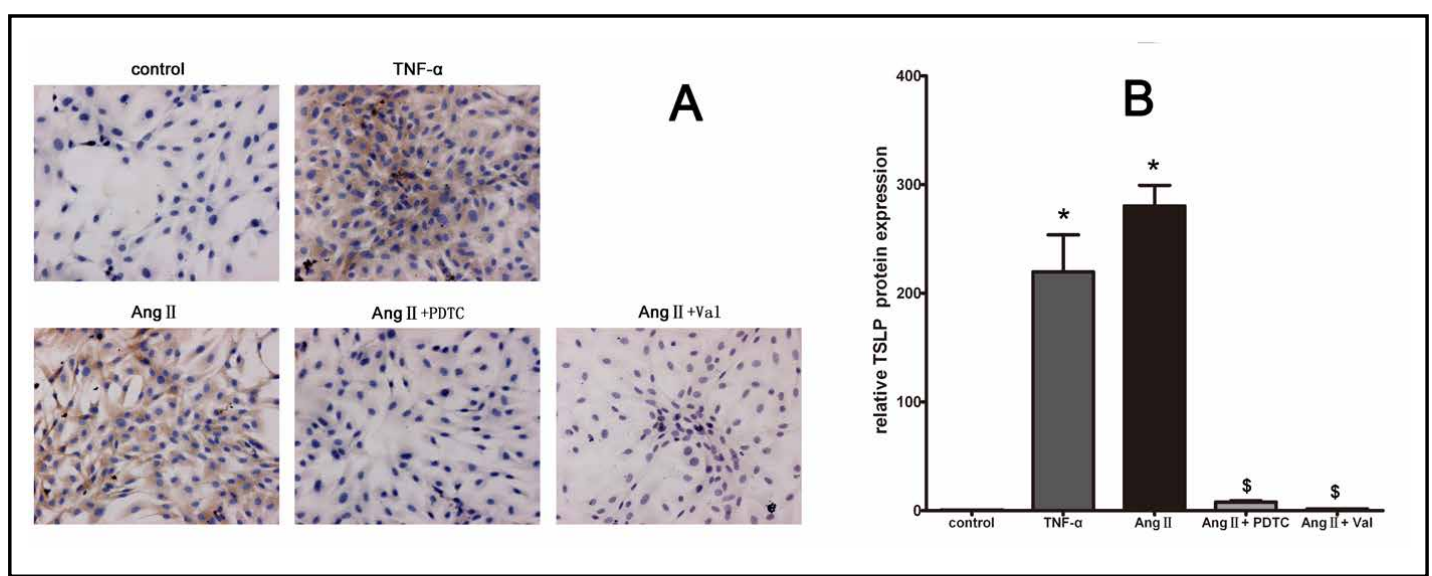

Fig. 1. Immunohistochemical staining analysis of the expression of TSLP in rat VSMCs. When seeded in a clear and semiconfluence vascular smooth muscle monolayer, cells were subjected to different treatment and stained by IHC. Cells were photographed directly under the telecytological microscope. Brown/black color displays the positive expression. A, Cells were incubated with NCS-free medium or stimulated with Ang II $(0.1 \mu \mathrm{mol} / \mathrm{L})$, TNF- $\alpha(10 \mathrm{ng} / \mathrm{mL})$, Ang II $(0.1 \mu \mathrm{mol} / \mathrm{L})$ plus PDTC $(10 \mu \mathrm{mol} / \mathrm{L})$, Ang II $(0.1 \mu \mathrm{mol} / \mathrm{L})$ plus valsartan $(10 \mu \mathrm{mol} / \mathrm{L})$ for $12 \mathrm{~h}$ (Original magnification: $\times 200)$. B, Bar graphs show mean optical density (MOD=integrated option density (IOD)/n) of TSLP staining by measuring on the images with the Software Image-Pro Plus. The figure shows one of three similar experiments. ${ }^{*} \mathrm{P}<0.001$ vs control, ${ }^{\$} \mathrm{P}<0.001$ vs Ang II.

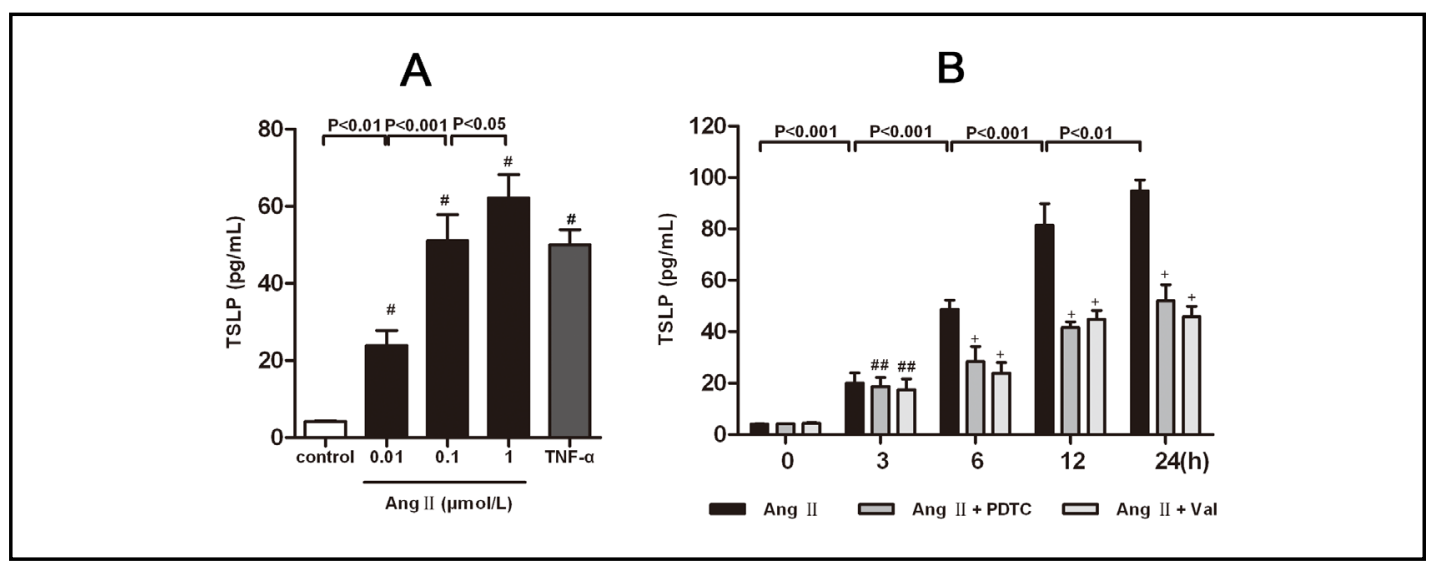

Fig. 2. Release of TSLP protein by VSMCs. Growth-arrested rat VSMCs were stimulated in the absence or presence of different concentrations of Ang II or Ang II with or without pretreatment for 30 minutes with PDTC, valsartan for different durations. TSLP accumulation in the culture supernatants was measured by ELISA assay. A, VSMCs were incubated with medium alone (control), increasing concentrations of Ang II $(0.01,0.1,1 \mu \mathrm{mol} / \mathrm{L})$, or TNF- $\alpha(10 \mathrm{ng} / \mathrm{mL})$ for $6 \mathrm{~h}$. B, VSMCs were incubated with medium alone $(0 \mathrm{~h}$, as a control) or Ang II $(0.1 \mu \mathrm{mol} / \mathrm{L})$ for $3,6,12$, and $24 \mathrm{~h}$ with or without pretreatment for 30 minutes with PDTC $(10 \mathrm{umol} / \mathrm{L})$, valsartan $(10 \mu \mathrm{mol} / \mathrm{L})$. Data are presented as mean \pm SD of at least three dependent experiments. ${ }^{\#} \mathrm{P}<0.01$ compared with the control group. ${ }^{\# \#} \mathrm{P}>0.5,{ }^{+} \mathrm{P}<0.001$, compared with the respective Ang II treated group.

TNF- $\alpha$-induced TSLP expression in human airway smooth muscle cells. The $\mathrm{AT}_{1}$ receptor plays an important role in the pathophysiology of Ang II action. Thus, to address the upstream regulatory mechanisms, we pretreated VSMCs with the NF- $\kappa B$ specific inhibitors PDTC $(10 \mu \mathrm{mol} / \mathrm{L})$ or the selective AT1 receptor antagonist valsartan $(10 \mu \mathrm{mol} / \mathrm{L})$ for $30 \mathrm{~min}$. Results showed significant decrease in TSLP expression on Ang II treatment (MOD $=7.89 \pm$ $1.29,1.51 \pm 0.19$, respectively, all $\mathrm{P}<0.001$ ). 


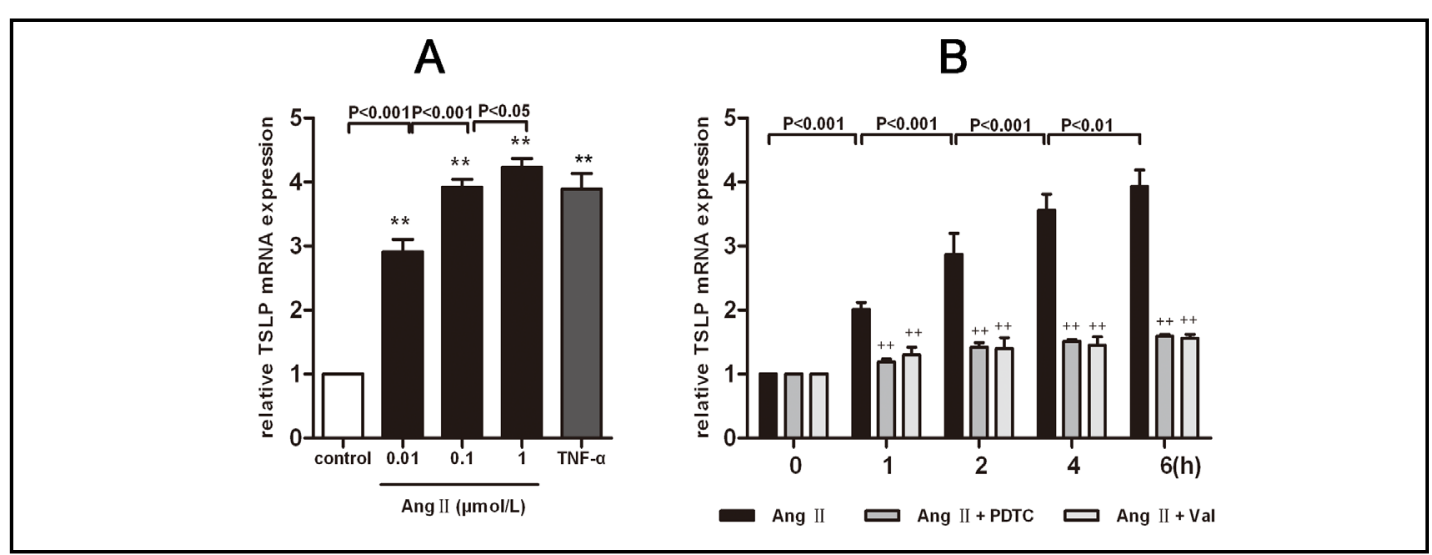

Fig. 3. Pro-inflammatory cytokine Ang II induced gene expression of TSLP in cultured VSMCs. The mRNA level of TSLP was determined by real-time RT-PCR analysis as described in Methods. GAPDH was used as an endogenous control. A, VSMCs were incubated with medium alone (control), increasing concentrations of Ang II $(0.01,0.1,1 \mu \mathrm{mol} / \mathrm{L})$, or TNF- $\alpha(10 \mathrm{ng} / \mathrm{mL})$ for $6 \mathrm{~h}$. B, VSMCs were incubated with medium alone $(0 \mathrm{~h}$, as a control) or Ang II $(0.1 \mu \mathrm{mol} / \mathrm{L})$ for $1,2,4$, and $6 \mathrm{~h}$ with or without pretreatment for 30 minutes with PDTC $(10 \mu \mathrm{mol} / \mathrm{L})$, valsartan $(10 \mu \mathrm{mol} / \mathrm{L})$. Data are presented as mean \pm SD of at least three dependent experiments. ${ }^{* *} \mathrm{P}<0.001$ compared with the control group. ${ }^{++} \mathrm{P}<0.001$, compared with the respective Ang II treated group.

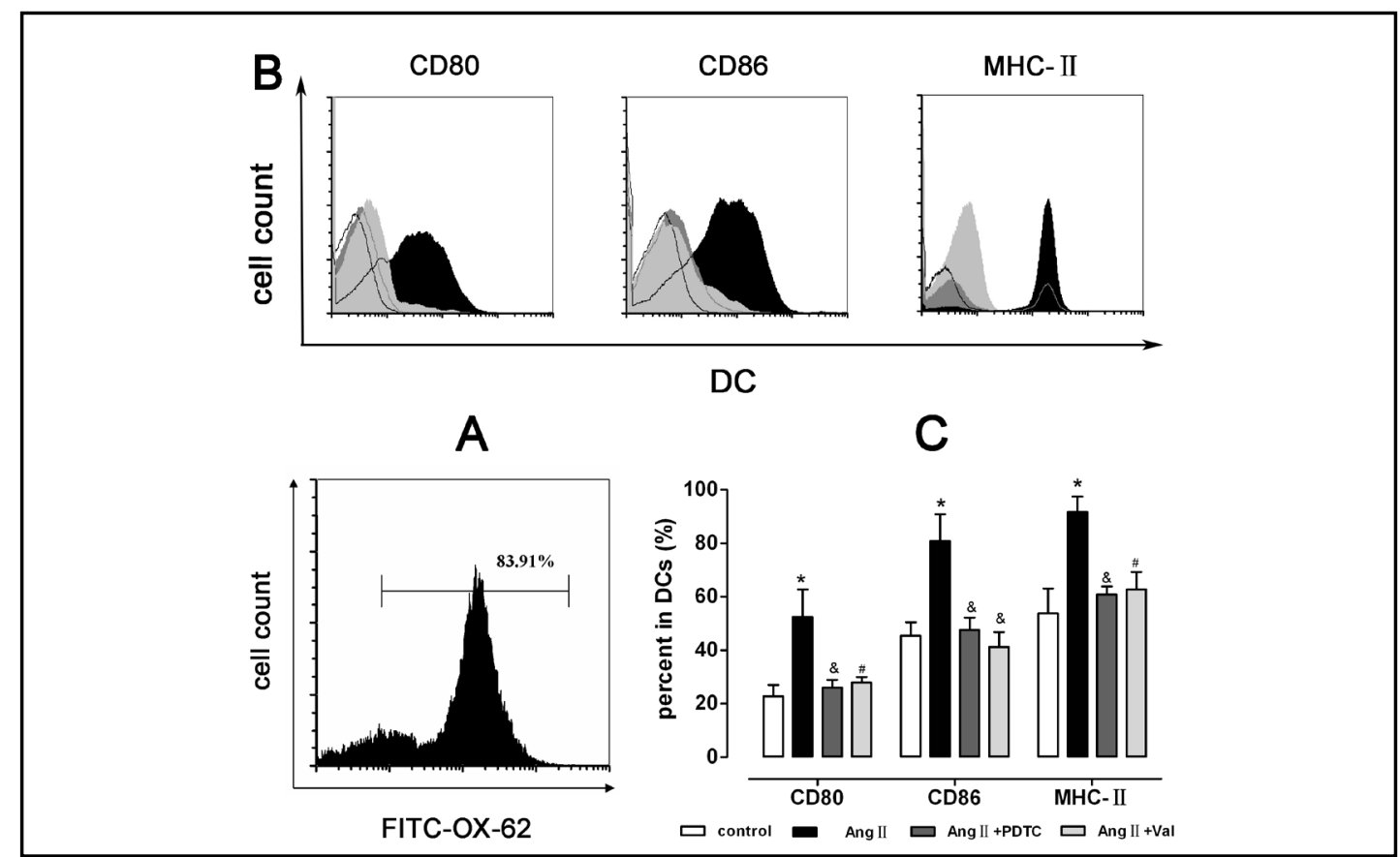

Fig. 4. Ang II-induced VSMCs promotes the expression of cell surface markers on DCs. A, mDCs were abtained from from the femurs and tibiae of SD rats. DCs purity was determined by the technique of flow cytometry with specific anti-rat OX-62 antibody labeled with FITC. B, DCs were stimulated with VSMCs from different groups. CD80, CD86 and MHC II expression was determined by flow cytometry. The legend in $C$ was also used here. C, Numbers indicate the percentage of positive-staining cells on DCs. Study data is representative of at least 3 separate flow cytometric analyses. ${ }^{*} \mathrm{P}<0.001$ vs control, ${ }^{*} \mathrm{P}<0.01$ vs Ang II, $\$ \mathrm{P}<0.01$ vs Ang II.

\section{ELISA Analysis of TSLP Protein Release in Cell Supernatants}

To further confirm this phenomenon at the protein level, we measured the level of TSLP in cell supernatants using ELISA. Serum-deprived VSMCs were stimulated with graded 


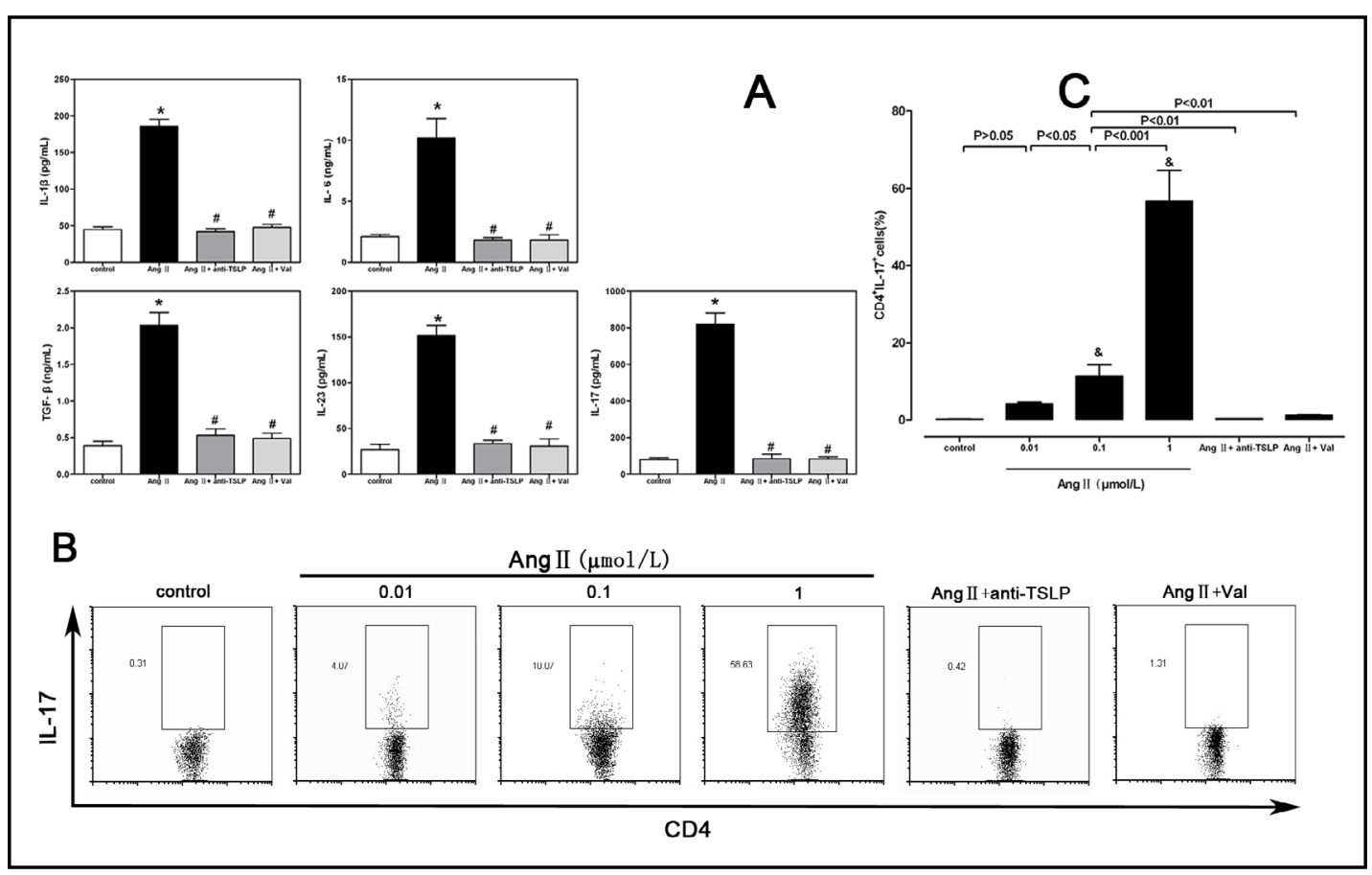

Fig. 5. In cultured VSMCs, Ang II induces TSLP production by DCs promoting Th17 differentiation. A, DCs were co-cultured with VSMCs from control, Ang II $(0.1 \mu \mathrm{mol} / \mathrm{L})$-treated groups, Ang II plus valsartantreated groups, with or without $20 \mu \mathrm{g} / \mathrm{mL}$ anti-TSLP neutralizing antibody for $48 \mathrm{~h}$. DCs were collected and washed with PBS. The remaining cells and $\mathrm{CD}^{+} \mathrm{T}$ cells were co-cultured at a DC/T-cell ratio of 1:5 for $48 \mathrm{~h}$. Supernatants in the coculture were tested for IL-1 $\beta$, IL-6, TGF- $\beta$, IL-23 and IL-17. B, CD4+ T cells were sequentially stained with FITC-conjugated anti-CD4 antibody and PE-conjugated anti-IL-17 antibody, and analyzed by flow cytometry in gated CD4+ $\mathrm{IL}-17^{+}$cells. In some experiments, DCs were cocultured with VSMCs from Ang II $(0.01,1 \mu \mathrm{mol} / \mathrm{L})$-treated groups, without anti-TSLP neutralizing antibody. Then DCs were cocultured with $\mathrm{CD} 4{ }^{+} \mathrm{T}$ cells as described above. C, Frequencies of $\mathrm{CD} 4{ }^{+} \mathrm{IL}-17^{+}$cells were analyzed statistically by SPSS17.0. Study data are representative of 3-4 independent experiments. ${ }^{*} \mathrm{P}<0.001$ vs control, ${ }^{*} \mathrm{P}<0.001$ vs Ang II, \& $\mathrm{P}<0.01$ vs control.

concentrations of Ang II $(0.01,0.1,1 \mu \mathrm{mol} / \mathrm{L})$, or medium alone for $6 \mathrm{~h}$. Few TSLP protein expression was detected for control groups. Stimulation with Ang II induced the release of TSLP in a concentration-dependent manner at $6 \mathrm{~h}$ (Fig. 2A). At 6-h time points, a statistically significant increase in TSLP release from rat VSMCs occurred with 0.01, 0.1, $1 \mu \mathrm{mol} / \mathrm{L}$ Ang II or $10 \mathrm{ng} / \mathrm{mL}$ TNF- $\alpha(\mathrm{P}<0.05)$. Upon Ang II $(0.1 \mu \mathrm{mol} / \mathrm{L})$ with or without PDTC $(10 \mu \mathrm{mol} / \mathrm{L})$ or valsartan $(10 \mu \mathrm{mol} / \mathrm{L})$ stimulation, we examined the release of the TSLP protein for different durations. Results showed that Ang II time-dependently induced the production of TSLP, meanwhile apart from 3-h time points (Fig. 2B, P > 0.05), PDTC or valsartan markedly suppressed Ang II -induced TSLP production $(\mathrm{P}<0.001)$.

Pro-inflammatory Mediator Ang II Induced Gene Expression of TSLP in Cultured VSMCs

Previous studies have shown that pro-inflammatory mediators IL- $1 \beta$ and TNF- $\alpha$ can induce TSLP mRNA expression in HASMCs in vitro. Moreover, based on our above findings, it was possible that Ang II, with or without PDTC or valsartan, affects TSLP expression by modulating the levels of TSLP mRNAs. To address this possibility, total cellular RNAs were isolated from VSMCs and analyzed by real-time RT-PCR using GAPDH mRNA as an internal reference for normalization. As shown in Fig. 3, in agreement with TSLP protein expression, there was a significant, dose-dependently increase compared with the control in TSLP mRNA expression following Ang II (0.01, 0.1, $1 \mu \mathrm{mol} / \mathrm{L})$ or TNF- $\alpha$ stimulation for $6 \mathrm{~h}$ (Fig. 3A, all 


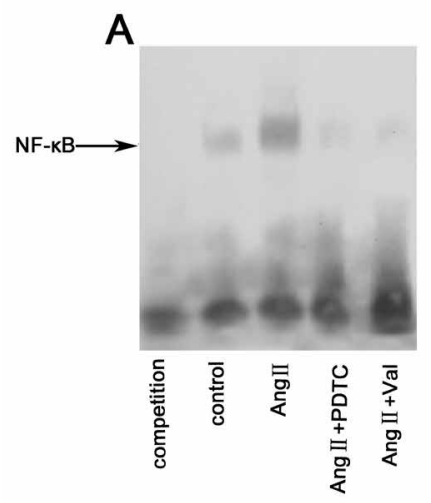

B

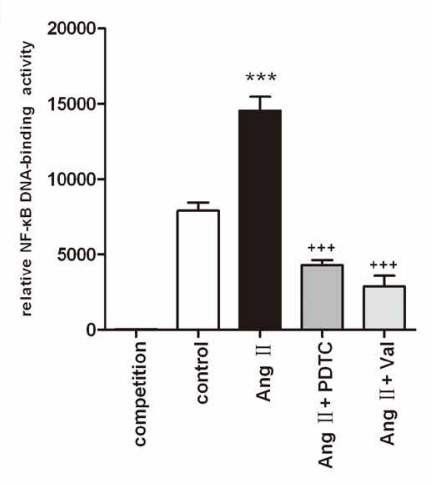

Fig. 6. The activation of NF- $\mathrm{B}$ in primary rat VSMCs exposed to Ang II. The co-culture system was set up as described in Figure legend 1. An electrophoretic mobility shift assay was performed with nuclear extracts ( $30 \mu \mathrm{g} /$ well) from VSMCs in different cultures to examine NF- $\kappa$ B activity. A, column 1 , competition of biotinlabeled probes with a 100 -fold excess of unlabeled probes for $12 \mathrm{~h}$. column 2, VSMCs cultured with NCS-free medium for $12 \mathrm{~h}$ (control). column 3, VSMCs co-cultured with Ang II ( $0.1 \mu \mathrm{mol} / \mathrm{L})$ for $12 \mathrm{~h}$. column 4, VSMCs were pretreated with PDTC $(10 \mu \mathrm{mol} / \mathrm{L})$ for 30 minutes and then stimulated with Ang II $(0.1 \mu \mathrm{mol} / \mathrm{L})$ for $12 \mathrm{~h}$. column 5 , VSMCs were pretreated with valsartan $(10 \mu \mathrm{mol} / \mathrm{L})$ for 30 minutes and then stimulated with Ang II $(0.1 \mu \mathrm{mol} / \mathrm{L})$ for $12 \mathrm{~h}$. Nuclear protein extracted from the Ang II system (column 3 ) showed strong binding activity for the NF- $\kappa \mathrm{B}$ oligonucleotide probes compared with that from the control culture (column 2). Binding specifically disappeared by excess unlabeled NF- $\kappa B$ oligonucleotide (column 1). VSMCs pretreated with PDTC or valsartan showed marked inactivation of NF- $\kappa$ B on Ang II treatment (column 4). B, DNA binding activity of NF- $\kappa B$ in different cultures in A was evaluated using the relative quantitive method (IOD). Data are expressed as mean \pm SD of at least 3 independent experiments. ${ }^{* * *} \mathrm{P}<0.001$ vs control, ${ }^{++} \mathrm{P}<0.001$ vs Ang II.

$\mathrm{P}<0.05)$. In addition, upon VSMCs exposing Ang II $(0.1 \mu \mathrm{mol} / \mathrm{L})$ for different durations (1, $2,4,6 \mathrm{~h}$ ), it is noteworthy that there was a time-dependent effect on TSLP mRNA production (Fig. 3B, P < 0.05). After pre-incubation of VSMCs with PDTC or valsartan in a similar fashion, the expression of TSLP mRNA was inhibited markedly (Fig. 3B, $\mathrm{P}<0.01$ ). Collectively, our current data establish the fact that Ang II induces the TSLP expression in VSMCs and PDTC or valsartan can reverse this process.

TSLP Induces the Differentiation of Th17 Cells by Triggering Dendritic Cells

The anti-OX-62 antibody recognizes the E2 integrin alpha chain expressed by rat DC. Previous study have successfully use OX-62 to identify DC in rats. As expected, the results of the flow cytometry revealed that after culture the specific expression of OX62 in rat DCs was $>83 \%$ (Fig. 4A). The expression of cell surface markers, such as CD80, CD86, and MHC II, is well used to assess the maturation status of DCs. On day 8 of culture, mDCs were concultured with VSMCs from different treated groups. Ang II-treated VSMCs up-regulates expressin of these molecules on mDCs compared with control group by flow cytometric analysis (Fig.4 B and C). When PDTC or valsartan was added in VCMCs culture circumstance, the expression of CD80, CD86, and MHC II on DCs were markedly reduced.

Th17 cells has for long been an area of active investigation. The differentiation of Th17 cells from naïve CD4 ${ }^{+}$T cells is regulated by many cytokines. IL- 6 and TGF- $\beta$ are dominant in the initiation of Th17 cell differentiation. IL-1 $\beta$ and IL-23 were believed to be important in expanding and maintaining the differentiation of Th17 cells. IL-17, as a signature cytokine in Th17 immune response, has been highlighted in patients with atherosclerosis or hypertension. It is known that in many immune related diseases, TSLP exerts profound influence on Th2 cell response by driving DC Maturation. More recently, there is compelling 
evidence that TSLP is involved in Th17 immune response in autoimmune and inflammation diseases. mDCs were co-cultured with VSMCs from Ang II $(0.1 \mu \mathrm{mol} / \mathrm{L})$-treated groups, with or without $20 \mu \mathrm{g} / \mathrm{mL}$ anti-TSLP neutralizing antibody. Then DCs and CD4 ${ }^{+} \mathrm{T}$ cells were cocultured for additional 48 hours. Th17-associated cytokines (IL-1 $\beta$, IL-6, TGF- $\beta$, IL-23, IL-17) in the supernatant were evaluated by ELISA assay (Fig. 5A). Ang II-treated groups displayed a significant increase in their capacity to produce IL-1 $\beta(185.36 \pm 9.88 \mathrm{pg} / \mathrm{mL}, \mathrm{P}<0.001)$, IL-6 $(10.19 \pm 1.60 \mathrm{ng} / \mathrm{mL}, \mathrm{P}<0.001)$, TGF- $\beta(2.03 \pm 0.18 \mathrm{ng} / \mathrm{mL}, \mathrm{P}<0.001)$, IL-23 (151.43 \pm $10.88 \mathrm{pg} / \mathrm{mL}, \mathrm{P}<0.001)$ and IL-17 (819.69 $\pm 61.50 \mathrm{pg} / \mathrm{mL}, \mathrm{P}<0.001)$, compared with those in the control $(44.87 \pm 3.57 \mathrm{pg} / \mathrm{mL}, 2.11 \pm 0.18 \mathrm{ng} / \mathrm{mL}, 0.39 \pm 0.06 \mathrm{ng} / \mathrm{mL}, 26.79 \pm 6.03$ $\mathrm{pg} / \mathrm{mL}, 80.70 \pm 9.32 \mathrm{pg} / \mathrm{mL}$, respectively). Anti-TSLP neutralizing antibody and valsartan significantly inhibit production of these cytokines (all $\mathrm{P}<0.001$ ), implying a TSLP-dependent process. As shown in Fig. 5, mDCs could effectively induce the differentiation of Th17 cells in Ang II-treated groups (apart from $0.01 \mu \mathrm{mol} / \mathrm{L})$. Upon Ang II $(0.1 \mu \mathrm{mol} / \mathrm{L})$ with anti-TSLP neutralizing antibody or valsartan stimulation, mDCs markedly inhibits the differentiation of Th17 cells compared with Ang II (0.1 $\mu \mathrm{mol} / \mathrm{L})$-treated groups.

\section{Ang II Upregulates NF- $\kappa B$ DNA binding Activity in VSMCS}

Nuclear factor $\kappa B(\mathrm{NF}-\kappa \mathrm{B})$, as a crucial transcription factor, is involved in the regulation of inflammatory and immune genes, cell proliferation, and apoptosis. To test the hypothesis that NF- $\kappa B$ might be involved in Ang II inducing TSLP on VSMCs, electrophoretic mobility shift assay (EMSA) was performed with specific oligonucleotide probes for the NF- $\mathrm{BB}$ binding site regions. As illustrated in Fig. 6, Ang II evoked a clear increase in binding of NF$\kappa \mathrm{B}$ consensus oligonucleotides with DNA (lane 3, integrated option density (IOD) $=14534$ $\pm 931.72, \mathrm{P}<0.001)$, compared with constitutive level of NF- $\kappa \mathrm{B}$ activation on primary rat VSMCs without treatment (lane 2, IOD $=7900 \pm 556.72$ ). By contrast, pre-incubation VSMCs with PDTC or valsartan, showed markedly diminished Ang II -induced NF- $\mathrm{KB}$ nuclear translocation (lane 4, IOD $=4288 \pm 333.05$, lane 5, IOD $=2874 \pm 709.97$, all $\mathrm{P}<0.001$ ). $\mathrm{NF}-\kappa \mathrm{B}$ complexes disappeared when competition experiments were performed with an excess of unlabeled NF- $\mathrm{BB}$ sequence, demonstrating the specificity of NF- $\kappa B$ DNA-binding (lane 1). It is plausible to postulate that Ang II induces the production of TSLP via the AT1 receptor/NF- $\mathrm{\kappa B}$ signaling pathway.

\section{Discussion}

The present study reveals several new findings concerning the relationship of Ang II and DCs in Th17 immune response of atherosclerosis and hypertension. First, in primary cultured VSMCs, Ang II induced the expression of TSLP at the level of protein and mRNA (Fig. 1-3). Second, Ang II up-regulated the expression of TSLP in VSMCs in concentrationand time-dependent ways (Figs 2 and 3). Ang II-treated VSMCs boosted the expression of the costimulatory molecules including CD80, CD86, and MHC II, confirming the maturation of DCs (Fig. 4). Furthermore, TSLP from Ang II-treated VSMCs potentially induce the differentiation of Th17 Cells by triggering DCs, as evident of the strong induction of the Th17 related cytokine secretion (IL-1 $\beta$, IL- 6 , TGF- $\beta$, IL-23, IL-17), and the production of the CD4 ${ }^{+}$ IL-17+ $\mathrm{T}$ cells (Fig. 5). Third, both NF- $\mathrm{KB}$ inhibitor PDTC and the AT1 receptor antagonist valsartan remarkably suppressed Ang II-induced TSLP production and DC activation in cultured VSMCs. (Fig. 2B, Fig. 3B and Fig. 4). Our present results further supported the fact that in VSMC culture, NF- $\kappa B$ activation is an important intracellular signaling for Ang IIinduced pro-inflammatory effects (Fig. 6) $[39,40]$. We speculated that the NF- $\kappa B$ pathway is likely to mediate Ang II-induced TSLP expression in VSMCs. Moreover, most of the known physiological and pathophysiological effects of Ang II are mediated by angiotensin type 1 receptors $[29,30]$. Considerable papers have shown that Ang II, mainly working via AT1 receptor on VSMCs, induces activation of NF- $\mathrm{KB}[52,53]$. Reasonably, based on these 
observations, we inferred that the AT1 receptor/NF- $\mathrm{KB}$ pathway might be involved in the regulation of Ang II-induced TSLP expression in VSMCs.

Angiotensin II not only mediates immediate physiological effects of vasoconstriction and blood pressure regulation [31], but is also implicated in the pathology of CVD by altering vasoreactivity and endothelial function, inducing VSMC proliferation and migration, promoting ROS production, inflammation, inciting leukocyte adhesion [24, 28, 45, 47]. Ang II give rise to an inflammatory response and activation of T cells in blood vessels [28, 47, 54]. Ang II can amplify Th17 response, playing an important role in Ang II-induced atherosclerosis and hypertension $[11,55]$. In the aortic media, Ang II infusion increases IL-17 production from T cells and IL-17 protein. The AT1 activation has a key role in these actions. The therapeutic use of ARB has extensively beneficial effects in attenuating the development of atherosclerosis and hypertension [29, 31-33]. Moreover, VSMCs play a fundamental role in maintaining vascular structure and function. In addition to contractile activity, VSMC proliferation and inflammation also participate in hypertension [44, 56, 57]. VSMCs are involved in atherosclerosis through a series of effects such as generating extracellular matrix protein, uptaking lipid, expressing adhesion molecules and cytokines [30, 44, 45, 58]. Upon Ang II stimulation, VSMCs produce ICAM-1, VCAM-1, and MCP-1, which can promote monocytes/macrophages and leukocytes adhesion and/or infiltration to accelerate the progression of cardiovascular dysfunction $[59,60]$. Our results showed that Ang II was able to induce TSLP production in VSMCs, which may complicate these responses.

Chronic inflammation has been advocated as one of the important etiological factors for CVD. Inflammation contributes to all stages of atherosclerosis, from its initiation through its progression and its ultimate complication of thrombosis [4, 5, 43, 47, 54]. Cytokines and inflammatory mediators work in concert with the direct effects of Ang II, catecholamines and salt to cause renal and vascular dysfunction in hypertension [7,61]. Studies carried out over the past few years have been immensely fruitful in terms of advances in our understanding of the adaptive immune mechanisms of atherosclerosis $[4,5,17,18]$. There was an increase in Th17 and IL-17 in atherosclerosis aorta in mice. Peripheral Th17 cell number and Th17associated cytokine (IL-17, IL-23 and IL-6) levels markedly increased in patients with acute coronary syndrome. Some people think that Th17/Treg imbalance plays an important role in plaque destabilization. Some elegant studies have shown that Th17 immune response plays an important modulatory role in hypertension $[11,14,28]$. Likewise, Th17 cells can modulate blood pressure and tissue injury in Ang II, Dahl salt-sensitive and deoxycorticosterone saltsensitive hypertension.

DCs which orchestrate adaptive immunity and act as sentinels that monitor the extracellular space in search for dangerous proteins and present to T cells via MHC molecules, and polarize naïve $\mathrm{T}$ cells into different effector $\mathrm{T}$ cells. In recent years, the pivotal role of DCs in adaptive immunity has been a focus of growing interest in CVD. Located DCs mainly are deposited in rupture-prone regions of the atherosclerotic plaques where they exhibit a mature phenotype [21]. In these areas, activated DCs were found to form direct contact with T lymphocytes [21,22] and conceivably may elicit a local immune response. The potential role of DCs in atherosclerosis and hypertension needs to be defined. Much attention has also been drawn to the role of TSLP, which drives DCs maturation and activation and further triggers immune response. Studies have established a direct link between TSLP, as a master switch Th2 driven allergic inflammation, and the pathogenesis of atopic dermatitis (AD) and asthma. TSLP can also sense the outside world and regulate barrier immunity in inflammatory bowel disease [37]. Additionally, TSLP has been found to be involved in autoimmune diseases [36] and chronic obstructive pulmonary disease (COPD) [41], which described it as a chronic inflammation disease with adaptive immune disorder. TSLP in the role of Th17 response remains poorly understood and is only beginning to be elucidated. Through DC activation, human TSLP and TLR3 ligands promoted differentiation of Th17 cells [36]. In the mouse models of arthritic, TSLP and its receptor can enhance Th17-driven arthritis and tissue destruction [62]. TSLP is closely associated with NF- $\kappa B$, which has gained acceptance as an influential nuclear transcription factor in atherosclerosis and hypertension. Th17 cells arise 
from differentiative signals from TGF- $\beta$, IL-1 and IL-6, while stability and maintenance of this cell type is mediated by IL-23. In this study, TSLP from Ang II-induced VSMCs elevates these Th17-associated cytokines secretion and induces the differentiation of Th17 Cells. We infer that through evoking Th17 immune response, TSLP may play a potential role in the development of atherosclerosis and hypertension

Prolonged activation of NF- $\mathrm{B}$, which may occur through persistence of the stimulating agent(s), is a common hallmark of atherosclerosis and hypertension [54,63]. Analysis of the TSLP gene promoter revealed an NFKB site $3.7 \mathrm{~kb}$ upstream of the transcription start site that was critical for this inducible expression [64]. The NF- $\kappa B$ activation has been reported to be involved in TSLP expression in airway epithelial cells (AECs) [64], HASMCs [41, 42], synovial fibroblasts [65], intervertebral disc cells [66], mast cells [67] and human corneal epithelial cells [38]. The angiotensin-converting enzyme inhibitor (enalapril) and an angiotensin II type 1 receptor blocker (losartan) provided renoprotective benefits in TSLPtg mice. Our study further highlights the importance of the AT1 receptor/NF- $\kappa B$ pathway in the regulation of TSLP expression.

Collectively, our study showed that pro-inflammatory cytokine Ang II induces TSLP expression in primary VSMCs. TSLP from Ang II-treated VSMCs induced the differentiation of Th17 Cells. AT1 receptor/NF- $\kappa B$ pathway may mediate Ang II-induced TSLP production in VSMCs. It will provide a novel line that Ang II stimulates TSLP expression in VSMCs, which is likely to attract DCs to local regions of vascular cell dysfunction and trigger Th17 cell immune responses, which participates in the development of atherosclerosis and hypertension. Our data have just started to appreciate the extraordinary life of TSLP and further supported the concept that Th17 cell immune mechanisms have a critical role in atherosclerosis and hypertension. Much work yet remains to be accomplished to advance our knowledge of the adaptive immunity in the pathogenesis of atherosclerosis and hypertension, which may help to successfully manipulate the two diseases.

\section{Acknowledgements}

We are thankful to all the anonymous reviewers for their help in preparation of this manuscript. This work was supported by grants from the National Natural Science Foundation of China, 30670855 and 81170258 to Li Dazhu and 81172781 to Li Ming.

\section{References}

1 deGoma EM, Knowles JW, Angeli F, Budoff MJ, Rader DJ: The evolution and refinement of traditional risk factors for cardiovascular disease. Cardiol Rev 2012;20:118-129.

- Wong ND, Nelson JC, Granston T, Bertoni AG, Blumenthal RS, Carr JJ, Guerci A, Jacobs DR Jr, Kronmal R, Liu K, Saad M, Selvin E, Tracy R, Detrano R: Metabolic syndrome, diabetes, and incidence and progression of coronary calcium: the Multiethnic Study of Atherosclerosis study. JACC Cardiovasc Imaging 2012;5:358366.

-3 Tocci G, Rosei EA, Ambrosioni E, Borghi C, Ferri C, Ferrucci A, Mancia G, Morganti A, Pontremoli R, Trimarco B, Zanchetti A, Volpe M: Blood pressure control in Italy: analysis of clinical data from 2005-2011 surveys on hypertension. J Hypertens 2012;30:1065-1074.

$\checkmark 4$ Lahoute C, Herbin 0, Mallat Z, Tedgui A: Adaptive immunity in atherosclerosis. Nat Rev Cardiol 2011;8:348-358.

5 Hansson GK, Hermansson A: The immune system in atherosclerosis. Nat Immunol 2011;12:204-212.

-6 Harrison DG, Vinh A, Lob H, Madhur MS: Role of the adaptive immune system in hypertension. Curr Opin Pharmacol 2010;10:203-207.

7 Harrison DG, Guzik TJ, Lob HE, Madhur MS, Marvar PJ, Thabet SR, Vinh A, Weyand CM: Inflammation, immunity, and hypertension. Hypertension 2011;57;132-140. 


\section{Cellular Physiology $\quad$ Cell Physiol Biochem 2012;30:1383-1397 and Biochemistry

8 Bi Y, Yang R: Direct and indirect regulatory mechanisms in TH17 cell differentiation and functions. Scand J Immunol 2012;75:543-52.

-9 Liu Z, Lu F, Pan H, Zhao Y, Wang S, Sun S, Li J, Hu X, Wang L: Correlation of peripheral Correlation of peripheral Th17 cells and Th17-associatedcytokines to the severity of carotidartery plaque and its clinical implication. Atherosclerosis 2012;221:232-241.

10 Chen S, Crother TR, Arditi M. Chen S, Crother TR, Arditi M: J Innate Immun 2010;2:325-333.

11 Madhur MS, Lob HE, McCann LA, Iwakura Y, Blinder Y, Guzik TJ, Harrison DG: Interleukin 17 promotes angiotensin II-induced hypertension and vascular dysfunction. Hypertension 2010;55:500-507.

$>12$ Usui F, Kimura H, Ohshiro T, Tatsumi K, Kawashima A, Nishiyama A, Iwakura Y, Ishibashi S, Takahashi M: Interleukin-17 deficiency reduced vascular inflammation and development of atherosclerosis in Western diet-induced apoE-deficient mice. Biochem Biophys Res Commun 2012;420:72-77.

$\checkmark 13$ Smith E, Prasad KM, Butcher M, Dobrian A, Kolls JK, Ley K, Galkina E: Blockade of interleukin-17A results in reduced atherosclerosis in apolipoprotein E-deficient mice. Circulation 2010;121:1746-1755.

14 Dhillon P, Wallace K, Herse F, Scott J, Wallukat G, Heath J, Moseley J, Martin JN Jr, Dechend R, Lamarca B: IL-17 mediated oxidative stress is an important stimulator of AT1-AA and hypertension during pregnancy. Am J Physiol Regul Integr Comp Physiol 2012;303:R353-R358.

15 Banchereau J, Steinman RM: Dendritic cells and the control of immunity. Nature 1998;392:245-252.

16 Laffont S, Powrie F: Immunology: Dendritic-cell genealogy. Nature 2009;462:732-733.

17 Zhang Y, Zhang C: Role of dendritic cells in cardiovascular diseases. World J Cardiol 2010;2:357-364.

18 Ranjit S, Li DZ, Zeng QT, Feng YB, Li YS, Wang X, Chao LS, Tian Y: Differentiation of dendritic cells in monocyte cultures isolated from patients with unstable angina. Int J Cardiol 2004;97:551-555.

19 Li D, Ranjit S, Zeng Q: Functional role of dendritic cells in patients with unstable angina. J Huazhong Univ Sci Technolog Med Sci 2005;25:397-9, 415.

-20 Wang L, Li D, Yang K, Hu Y, Zeng Q: Toll-like receptor-4 and mitogen-activated protein kinase signal system are involved in activation of dendritic cells in patients with acute coronary syndrome. Immunology 2008;125:122-130.

-21 Yilmaz A, Lochno M, Traeg F, Cicha I, Reiss C, Stumpf C, Raaz D, Anger T, Amann K, Probst T, Ludwig J, Daniel WG, Garlichs CD: Emergence of dendritic cells in rupture-prone regions of vulnerable carotid plaques. Atherosclerosis 2004;176:101-110.

-22 Bobryshev YV, Lord RSA: Mapping of vascular dendritic cells in atherosclerotic arteries suggests their involvement in local immune-inflammatory reactions. Cardiovasc Res 1998;37:799-810.

23 Harrison DG, Marvar PJ, Titze JM: Vascular inflammatory cells in hypertension. Front Physiol 2012;3:128.

24 Sata M, Fukuda D: Crucial role of renin-angiotensin system in the pathogenesis of atherosclerosis. J Med Invest 2010;57:12-25.

-25 Schmieder RE, Hilgers KF, Schlaich MP, Schmidt BM: Renin-angiotensin system and cardiovascular risk. Lancet 2007;369:1208-1219.

26 Matsuo H, Ichikawa S, Sakamaki T, Ono Z, Kumakura H, Nakamura T, Murata K: Enhanced responses to pressor stimuli by intracerebroventricular infusions of angiotensin II in conscious rats. Jpn Circ J 1986;50:270-277.

-27 Saiki Y, Watanabe T, Tan N, Matsuzaki M, Nakamura S: Role of central ANG II receptors in stress-induced cardiovascular and hyperthermic responses in rats. Am J Physiol 1997;272:R26-R33.

$>28$ Guzik TJ, Hoch NE, Brown KA, McCann LA, Rahman A, Dikalov S, Goronzy J, Weyand C, Harrison DG: Role of the $\mathrm{T}$ cell in the genesis of angiotensin II induced hypertension and vascular dysfunction. J Exp Med 2007;204:2449-2460.

29 Billet S, Aguilar F, Baudry C, Clauser E: Role of angiotensin II AT1 receptor activation in cardiovascular diseases. Kidney Int 2008;74:1379-1384.

-30 Mehta PK, Griendling KK: Angiotensin II cell signaling: physiological and pathological effects in the cardiovascular system. Am J Physiol Cell Physiol 2007;292:C82-C97.

-31 Ismail H, Mitchell R, McFarlane SI, Makaryus AN: Pleiotropic effects of inhibitors of the RAAS in the diabetic population: above and beyond blood pressure lowering. Curr Diab Rep 2010;10:32-36.

32 Kohno T, Anzai T, Naito K, Sugano Y, Maekawa Y, Takahashi T, Yoshikawa T, Ogawa S: Angiotensinreceptor blockade reduces border zone myocardial monocyte chemoattractant protein-1 expression and macrophage infiltration in post-infarction ventricular remodeling. Circ J 2008;72:1685-1692. 


\section{Cellular Physiology $\quad$ Cell Physiol Biochem 2012;30:1383-1397 and Biochemistry

-33 Sawada T, Yamada H, Dahlöf B, Matsubara H; KYOTO HEART Study Group: Effects of valsartan on morbidity and mortality in uncontrolled hypertensive patients with high cardiovascular risks: KYOTO HEART Study. Eur Heart J 2009;30:2461-2469.

-34 Takai T: TSLP expression: cellular sources, triggers, and regulatory mechanisms. Allergol Int 2012;61:3-17.

-35 Soumelis V, Reche PA, Kanzler H, Yuan W, Edward G, Homey B, H, Gilliet M, Ho S, Antonenko S, Lauerma A, Smith K, Gorman D, Zurawski S, Abrams J, Menon S, McClanahan T, de Waal-Malefyt Rd R, Bazan F, Kastelein RA, Liu YJ: Human epithelial cells trigger dendritic cell-mediated allergic inflammation by producing TSLP. Nat Immunol 2002;3:673-680.

-36 He R, Geha RS: Thymic stromal lymphopoietin. Ann N Y Acad Sci 2010;1183:13-24.

-37 Ziegler SF, Artis D: Sensing the outside world: TSLP regulates barrier immunity. Nat Immunol 2010;11:289293.

- 38 Ma P, Bian F, Wang Z, Zheng X, Chotikavanich S, Pflugfelder SC, Li DQ: Human corneal epithelium-derived thymic stromal lymphopoietin links the innate and adaptive immune responses via TLRs and Th2 cytokines. Invest Ophthalmol Vis Sci 2009;50:2702-2709.

-39 Tanaka J, Watanabe N, Kido M, Saga K, Akamatsu T, Nishio A, Chiba T: Human TSLP and TLR3 ligands promote differentiation of Th17 cells with a central memory phenotype under Th2-polarizing conditions. Clin Exp Allergy 2009;39: 89-100.

40 Spadoni I, Iliev ID, Rossi G, Rescigno M: Dendritic cells produce TSLP that limits the differentiation of Th17 cells, fosters Treg development, and protects against colitis. Mucosal Immuno. 2012;5:184-193.

41 Zhang K, Shan L, Rahman MS, Unruh H, Halayko AJ, Gounni AS: Constitutive and inducible thymic stromal lymphopoietin expression in human airway smooth muscle cells: role in chronic obstructive pulmonary disease. Am J Physiol Lung Cell Mol Physiol 2007;293:L375-L382.

-42 Redhu NS, Saleh A, Halayko AJ, Ali AS and Gounni AS: Essential role of NF- $\kappa$ B and AP-1 transcription factors in TNF- $\alpha$-induced TSLP expression in human airway smooth muscle cells. Am J Physiol Lung Cell Mol Physiol 2011;300:L479-L485.

43 Doran AC, Meller D, McNamara CA: Role of smooth muscle cells in the initiation and early progression of atherosclerosis. Arterioscler Thromb Vasc Biol 2008;28:812-819.

44 Lee SJ, Kim WJ, Moon SK: TNF- $\alpha$ regulates vascular smooth muscle cell responses in genetic hypertension. Int Immunopharmacol 2009;9:837-843.

45 Ruiz-Ortega M, Lorenzo O, Ruperez M, Esteban V, Suzuki Y, Mezzano S, Plaza JJ, Egido J: Role of the reninangiotensin system in vascular diseases: expanding the field. Hypertension 2001;38:1382-1387.

-46 Ruiz-Ortega M, Lorenzo O, Ruperez M, Konig S, Wittig B, Egido J: Angiotensin II activates nuclear transcription factor $\kappa$ B through AT1 and AT2 in vascular smooth muscle cells: molecular mechanisms. Circ Res 2000;86:1266-1272.

-47 Schieffer B, Schieffer E, Hilfiker-Kleiner D, Hilfiker A, Kovanen PT, Kaartinen M, Nussberger J, Harringer W, Drexler H: Expression of angiotensin II and interleukin 6 in human coronary atherosclerotic plaques: potential implications for inflammation and plaque instability. Circulation 2000;101:1372-1378.

48 Guo S, Kowalewska J, Wietecha TA, Iyoda M, Wang L, Yi K, Spencer M, Banas M, Alexandrescu S, Hudkins $\mathrm{KL}$, Alpers CE: Renin-angiotensin system blockade is renoprotective in immune complex-mediated glomerulonephritis. J Am Soc Nephrol 2008;19:1168-1176.

-49 Jovinge S, Hultgårdh-Nilsson A, Regnström J, Nilsson J: Tumor necrosis factor-alpha activates smooth muscle cell migration in culture and is expressed in the balloon-injured rat aorta. Arterioscler Thromb Vasc Biol 1997;17:490-497.

50 Qiao J, Li A, Jin X: TSLP from RSV-stimulated rat airway epithelial cells activates activates myeloid dendritic cells. Immunol Cell Biol 2011;89:231-238.

51 Wang Q, Gao HB: Involvement of nuclear factor-kappa B on corticosterone-induced rat Leydig cell apoptosis. Asian J Androl 2006;8:693-702.

52 Li XC, Zhuo JL: Nuclear factor- $\mathrm{kB}$ as a hormonal intracellular signaling molecule: focus on angiotensin II -induced cardiovascular and renal injury. Curr Opin Nephrol Hypertens 2008;17:37-43.

53 Phillips MI, Kagiyama S: Angiotensin II as a pro-inflammatory mediator. Curr Opin Investig Drugs 2002;3:569-577.

54 Luft FC: Angiotensin, Inflammation, hypertension, and cardiovascular disease. Curr Hypertens Rep 2001;3:61-67. 


\section{Cellular Physiology $\quad$ Cell Physiol Biochem 2012;30:1383-1397 and Biochemistry

55 Liu XH, Ji QW, Huang Y, Zeng QT: Th17 response promotes angiotensin II-induced atherosclerosis. Med Hypotheses 2011;76:593-595.

-56 Arribas MS, Hermida C, González MC, Wang Y, Hinek A: Enhanced survival of vascular smooth muscle cells accounts for heightened elastin deposition in arteries of neonatal spontaneously hypertensive rats. Exp Physiol 2010;95:550-560.

57 Raines EW, Ferri N: Cytokines affecting endothelial and smooth muscle cells in vascular disease. J Lipid Res 2005;46:1081-1092.

-58 Guo R-W, Yang L-X, Wang H, Liu B, Wang L: Angiotensin II induces matrix metalloproteinase-9 expression via a nuclear factor-kappaB-dependent pathway in vascular smooth muscle cells. Regulatory Peptides 2008;147:37-44.

-59 Liu J, Yang F, Yang X-P, Jankowski M, Pagano P: NAD(P)H oxidase mediates Angiotensin II-induced vascular macrophage infiltration and medial hypertrophy. Arterioscler Thromb Vasc Biol 2003;23:776-782.

60 Nobuhiko A, Suganuma E, Babaev VR, Fogo A, Swift LL, Linton MF, Fazio S, Ichikawa I, Kon V: Angiotensin II amplifies macrophage-driven atherosclerosis. Arterioscler Thromb Vasc Biol 2004;24:2143-2148.

61 Marvar PJ, Lob H, Vinh A, Zarreen F, Harrison DG: The central nervous system and inflammation in hypertension. Curr Opin Pharmacol 2010;11:1-6.

-62 Hartgring SA, Willis CR, Dean CE Jr, Broere F, van Eden W, Bijlsma JW, Lafeber FP, van Roon JA: Critical proinflammatory role of thymic stromal lymphopoietin and its receptor in experimental autoimmune arthritis. Arthritis Rheum 2011;63:1878-1887.

63 de Winther MPJ, Kanters E, Kraal G, Hofker MH: Nuclear factor $\kappa B$ signaling in atherogenesis. Arterioscler Thromb Vasc Biol 2005;25:904-914.

64 Lee HC, Ziegler SF: Inducible expression of the proallergic cytokine thymic stromal lymphopoietin in airway epithelial cells is controlled by NFKB. Proc Natl Acad Sci USA 2007;104:914-919.

-65 Sebastian K, Borowski A, Kuepper M, Friedrich K: Signal transduction around thymic stromal lymphopoietin (TSLP) in atopic asthma. Cell Commun Signal 2008;6:5.

66 Ohba T, Haro H, Ando T, Koyama K, Hatsushika K, Suenaga F, Ohnuma Y, Nakamura Y, Katoh R, Ogawa H, Hamada Y, Nakao A: A potential role of thymic stromal lymphopoietin in the recruitment of macrophages to mouse intervertebral disc cells via monocyte chemotactic protein 1 induction: implications for herniated discs. Arthritis Rheum 2008;58:3510-3519.

67 Moon PD, Kim HM: Thymic stromal lymphopoietin is expressed and produced by caspase-1/NF- $\mathrm{B}$

pathway in mast cells. Cytokine 2011;54:239-243. 